TITLE:

\title{
High-capacity FeTiO/C negative electrode for sodium-ion batteries with ultralong cycle life
}

\section{$\operatorname{AUTHOR}(\mathrm{S}):$}

Ding, Changsheng; Nohira, Toshiyuki; Hagiwara, Rika

\section{CITATION:}

Ding, Changsheng ... [et al]. High-capacity FeTiO/C negative electrode for sodium-ion batteries with ultralong cycle life. Journal of Power Sources 2018, 388: 19-24

ISSUE DATE:

2018-06-01

URL:

http://hdl.handle.net/2433/245142

\section{RIGHT:}

(c) 2018. This manuscript version is made available under the CC-BY-NC-ND 4.0 license

http://creativecommons.org/licenses/by-nc-nd/4.0/:; The full-text file will be made open to the public on 1 June 2020 in accordance with publisher's 'Terms and Conditions for Self-Archiving'.; この論文は出版社版でありません。引用の際に は出版社版をご確認ご利用ください。; This is not the published version. Please cite only the published version. 


\section{High-capacity $\mathrm{FeTiO}_{3} / \mathrm{C}$ negative electrode for sodium-ion batteries with ultralong cycle life}

Changsheng Ding, ${ }^{a}$ Toshiyuki Nohira ${ }^{\mathrm{b}}$ and Rika Hagiwara ${ }^{\mathrm{a}}$

${ }^{\text {a }}$ Graduate School of Energy Science, Kyoto University, Sakyo-ku, Kyoto 606-8501, Japan

${ }^{\mathrm{b}}$ Institute of Advanced Energy, Kyoto University, Uji, Kyoto 611-0011, Japan

* Corresponding authors. Tel.: +81 75753 5822; Fax: +81 757535906.

E-mail addresses: nohira.toshiyuki.8r@kyoto-u.ac.jp (T. Nohira)

hagiwara@energy.kyoto-u.ac.jp (R. Hagiwara) 


\section{Abstract}

The development of electrode materials which improve both the energy density and cycle life is one of the most challenging issues facing the practical application of sodium-ion batteries today. In this work, $\mathrm{FeTiO}_{3} / \mathrm{C}$ nanoparticles are synthesized as negative electrode materials for sodium-ion batteries. The electrochemical performance and charge-discharge mechanism of the $\mathrm{FeTiO}_{3} / \mathrm{C}$ negative electrode are investigated in an ionic liquid electrolyte at $90{ }^{\circ} \mathrm{C}$. The $\mathrm{FeTiO}_{3} / \mathrm{C}$ negative electrode delivers a high reversible capacity of $403 \mathrm{mAh} \mathrm{g}^{-1}$ at a current rate of $10 \mathrm{~mA} \mathrm{~g}^{-1}$, and exhibits high rate capability and excellent cycling stability for up to 2000 cycles. The results indicate that $\mathrm{FeTiO}_{3} / \mathrm{C}$ is a promising negative electrode material for sodium-ion batteries.

Keywords: Sodium ion batteries; Negative electrode materials; High capacity; High stability; Charge-discharge mechanism

\section{Introduction}

Development of renewable energy generation and electric vehicles (EVs) has resulted in a rapid increase in the demand for large-scale energy storage systems. Sodium-ion batteries, as large-scale energy storage systems, have been attracting much attention for application in EVs and stationary energy storage systems because of the abundant resources and low cost of sodium [1-3]. Although sodium-ion batteries are being studied since the past three decades [4], extensive efforts have been devoted to develop lithium-ion batteries because of their high 
energy density. For practical application of sodium-ion batteries, it is necessary to develop new electrode materials with high capacities, good rate capabilities, and long cycle lives.

In recent years, many materials, including alloy materials [5-8], carbon materials [9-12], and transition metal oxide materials [13-18], have been investigated as negative electrode materials for sodium-ion batteries. Among them, transition metal oxides are attracting increasing attention due to their high volume capacities and safety. The reaction mechanism of transition metal oxides with $\mathrm{Na}$ generally differs from the classical $\mathrm{Na}$ insertion/extraction or Na-alloying processes. It usually involves the reduction and oxidation of the transition metal, leading to the formation and decomposition of $\mathrm{Na}_{2} \mathrm{O}$, which can give a relatively high theoretical capacity because of the multiple electron exchange per transition metal. $\mathrm{NiCo}_{2} \mathrm{O}_{4}$ was the first negative electrode material to be investigated; it afforded a reversible capacity of $200 \mathrm{mAh} \mathrm{g}^{-1}$ with a first charge capacity of $618 \mathrm{mAh} \mathrm{g}^{-1}$ and the formation of metallic $\mathrm{Ni}$ and $\mathrm{Co}$ [13]. $\mathrm{Fe}_{2} \mathrm{O}_{3}$ has also been used as a negative electrode material with high reversible capacities of 420-550 mAh $\mathrm{g}^{-1}$ in organic electrolytes $[14,16,19]$; however, their cycle performance was relatively poor. $\mathrm{Co}_{3} \mathrm{O}_{4}$ was reported to have reversible capacities of $440-516 \mathrm{mAh} \mathrm{g}^{-1}$ in the voltage range of 0.01-3.0 V $[20,21] . \mathrm{MoO}_{3}$ was also investigated as a high-performance negative electrode material and showed a reversible capacity of $410 \mathrm{mAh} \mathrm{g}^{-1}$ in the voltage range of $0.04-3.0 \mathrm{~V}$ [22]. However, both $\mathrm{Co}_{3} \mathrm{O}_{4}$ and $\mathrm{MoO}_{3}$ exhibit relatively poor cycle performance.

Recently, anatase $\mathrm{TiO}_{2}$ was investigated as a negative electrode material and showed reversible capacities of $193-275 \mathrm{mAh} \mathrm{g}^{-1}$ and good cycle stability [17,23]. In terms of earthabundance and environmental friendliness, Ti-based and Fe-based transition metal oxides are promising negative electrode materials for sodium-ion batteries. In view of the advantages of $\mathrm{TiO}_{2}$ and $\mathrm{Fe}_{2} \mathrm{O}_{3}$, new negative electrode materials can be developed by combining them. In this study, we develop a negative electrode material comprising $\mathrm{FeTiO}_{3}$ for sodium-ion batteries. To improve the electrochemical performance, nanostructuring and carbon-coating are also used. 
$\mathrm{Yu}$ et al. recently reported a $\mathrm{FeTiO}_{3}$-based negative electrode with tiny ilmenite $\mathrm{FeTiO}_{3}$ nanoparticle embedded carbon nanotubes (carbon content: $28.69 \mathrm{wt} \%$ ), which presents an excellent cycle stability and remarkable rate capability [24]. This indicates that the addition of carbon can effectively improve the electrochemical performance of $\mathrm{FeTiO}_{3}$. However, the carbon content is relatively high in the $\mathrm{FeTiO}_{3}$ nanoparticle embedded carbon nanotubes. In this work, we synthesize carbon-coated $\mathrm{FeTiO}_{3}\left(\mathrm{FeTiO}_{3} / \mathrm{C}\right)$ nanoparticles with low carbon content and report for the first time the charge-discharge performance of $\mathrm{FeTiO}_{3} / \mathrm{C}$ electrodes for sodium-ion batteries in ionic liquid electrolyte at $90{ }^{\circ} \mathrm{C}$. Ionic liquids have non-flammability, negligible volatility, high thermal and electrochemical stability, and relatively high ionic conductivity, and they have been regarded as promising electrolytes for sodium-ion batteries [23, 25-27]. Compared with the conventional organic electrolytes, ionic liquid electrolytes are very safe, especially at high temperatures. The use of ionic liquid electrolytes can solve the safety issue of sodium-ion batteries, especially for large-scale applications.

\section{Experimental section}

Commercial anatase $\mathrm{TiO}_{2}$ nanoparticles (Sigma Aldrich, USA), $\mathrm{Fe}\left(\mathrm{NO}_{3}\right)_{3} \cdot 9 \mathrm{H}_{2} \mathrm{O}$ (Wako, Japan), and sucrose (Sigma Life Science, USA) were used as the raw materials to synthesize carbon-coated $\mathrm{FeTiO}_{3}\left(\mathrm{FeTiO}_{3} / \mathrm{C}\right)$ nanoparticles. $\mathrm{Fe}\left(\mathrm{NO}_{3}\right)_{3} \cdot 9 \mathrm{H}_{2} \mathrm{O}$ was firstly dissolved in ethanol under stirring at the room temperature. $\mathrm{TiO}_{2}$ nanoparticles were then dispersed in the $\mathrm{Fe}\left(\mathrm{NO}_{3}\right)_{3}$ solution with the molar ratio of 1:1 to form a suspension by magnetic stirring. After drying, the mixture of $\mathrm{TiO}_{2}$ and $\mathrm{Fe}\left(\mathrm{NO}_{3}\right)_{3}$ was heated at $300{ }^{\circ} \mathrm{C}$ for $3 \mathrm{~h}$ in air. The obtained powders were then mixed with sucrose (10 wt\% carbon) by a mortar and pestle. Finally, the mixture was heated in $\mathrm{Ar}$ atmosphere at $600{ }^{\circ} \mathrm{C}$ for $5 \mathrm{~h}$ to obtain $\mathrm{FeTiO}_{3} / \mathrm{C}$ nanoparticles. 
The crystal phase of the synthesized $\mathrm{FeTiO}_{3} / \mathrm{C}$ nanoparticles was analyzed by X-ray diffraction (XRD; Rigaku SmartLab) using $\mathrm{Cu} K \alpha$ radiation. The morphology of the synthesized $\mathrm{FeTiO}_{3} / \mathrm{C}$ nanoparticles was observed by field emission scanning electron microscopy (FE-SEM; Hitachi SU8000) with energy dispersive X-ray spectroscopy (EDX) analysis. The carbon content of the $\mathrm{FeTiO}_{3} / \mathrm{C}$ nanoparticles was measured by a $\mathrm{CHN}$ analyzer.

The electrochemical tests were performed using coin-type 2032 cells with a sodium foil as the counter electrode at $90{ }^{\circ} \mathrm{C}$. The $\mathrm{FeTiO}_{3} / \mathrm{C}$ electrodes were fabricated by a conventional coating method. A slurry consisting of $\mathrm{FeTiO}_{3} / \mathrm{C}(80 \mathrm{wt} \%)$, acetylene black (10 wt $\left.\%\right)$, and polyamide-imide (PAI) (10 wt\%) in $N$-methyl-2-pyrrolidone (NMP) was uniformly spread onto an $\mathrm{Al}$ foil. The $\mathrm{FeTiO}_{3} / \mathrm{C}$ electrodes were dried in vacuo at $120^{\circ} \mathrm{C}$ overnight before transferring into an Ar-filled glovebox. The mass loading of $\mathrm{FeTiO}_{3} / \mathrm{C}$ material was $0.8-1.3 \mathrm{mg} \mathrm{cm}^{-2}$. The $\mathrm{Na}[\mathrm{FSA}]-\left[\mathrm{C}_{3} \mathrm{C}_{1}\right.$ pyrr][FSA $]$ (FSA $=$ bis(fluorosulfonyl)amide; $\mathrm{C}_{3} \mathrm{C}_{1}$ pyrr $=N$-methyl- $N$ propylpyrrolidinium) ionic liquid was used as the electrolyte with a molar ratio of 2:8. The measuring temperature of $90{ }^{\circ} \mathrm{C}$ was adopted because the $\mathrm{Na}[\mathrm{FSA}]-\left[\mathrm{C}_{3} \mathrm{C}_{1}\right.$ pyrr][FSA] ionic liquid exhibits good ionic conductivity and low viscosity at high temperatures [26]. Glass fiber filters (Whatman, GF-A, $260 \mathrm{~mm}$ ) were used as separators. The working electrodes and separators were vacuum-impregnated with the $\mathrm{Na}[\mathrm{FSA}]-\left[\mathrm{C}_{3} \mathrm{C}_{1}\right.$ pyrr][FSA] ionic liquid before assembling the cells. Charge-discharge testing was conducted at constant current rates of 10$2000 \mathrm{~mA} \mathrm{~g}^{-1}$ in the voltage range of $0.01-2.5 \mathrm{~V}$. After the charge-discharge tests, the $\mathrm{FeTiO}_{3} / \mathrm{C}$ electrodes were removed from the testing coin cells and were washed to remove the ionic liquid electrolyte by anhydrous tetrahydrofuran (THF; Wako Pure Chemicals) in an Ar-filled glovebox. The crystal structure and morphology of the $\mathrm{FeTiO}_{3} / \mathrm{C}$ electrodes were investigated by XRD and SEM, where the $\mathrm{FeTiO}_{3} / \mathrm{C}$ electrodes were sealed in an airtight sample holder to avoid air exposure. 


\section{Results and discussion}

Figure 1a shows the XRD pattern of the synthesized $\mathrm{FeTiO}_{3} / \mathrm{C}$ nanoparticles. All diffraction peaks are indexed to the ilmenite $\mathrm{FeTiO}_{3}$ structure (JCPDS file No. 01-079-1838), indicating the formation of single-phase $\mathrm{FeTiO}_{3}$. The average crystallite size of the $\mathrm{FeTiO}_{3} / \mathrm{C}$ nanoparticles is ca. $30 \mathrm{~nm}$ according to the Scherrer's formula. The carbon content of the $\mathrm{FeTiO}_{3} / \mathrm{C}$ nanoparticles was determined to be $4.8 \mathrm{wt} \%$ by a $\mathrm{CHN}$ analyzer. The SEM image of the synthesized $\mathrm{FeTiO}_{3} / \mathrm{C}$ nanoparticles is shown in Fig. 1b. The average particle size of the $\mathrm{FeTiO}_{3} / \mathrm{C}$ nanoparticles is less than $100 \mathrm{~nm}$.

Figure 2a shows the charge-discharge curves of the $\mathrm{FeTiO}_{3} / \mathrm{C}$ electrode at a current rate of $10 \mathrm{~mA}\left(\mathrm{~g}-\mathrm{FeTiO}_{3} / \mathrm{C}\right)^{-1}$ in the voltage range of $0.01-2.5 \mathrm{~V}$. In the first charge process, a large capacity of $834 \mathrm{mAh}\left(\mathrm{g}-\mathrm{FeTiO}_{3} / \mathrm{C}\right)^{-1}$ was observed with two distinct voltage plateaus at around 1.6 $\mathrm{V}$ and $0.5 \mathrm{~V}$. The plateau at $1.6 \mathrm{~V}$ is attributable to some side reactions, including the electrolyte reduction and formation of a solid-electrolyte interphase $[23,28]$, and it disappears in the subsequent cycles. The voltage plateau at $0.5 \mathrm{~V}$ possibly corresponds to the insertion of $\mathrm{Na}$ ions into $\mathrm{FeTiO}_{3} / \mathrm{C}$. In the first discharge process, there are two voltage plateaus at ca. 0.8 $\mathrm{V}$ and $1.7 \mathrm{~V}$ which correspond to extraction reaction of $\mathrm{Na}$ ions from $\mathrm{FeTiO}_{3} / \mathrm{C}$ electrode, giving a discharge capacity of $390 \mathrm{mAh}\left(\mathrm{g}-\mathrm{FeTiO}_{3} / \mathrm{C}\right)^{-1}$. The observed high irreversible capacity of $444 \mathrm{mAh}\left(\mathrm{g}-\mathrm{FeTiO}_{3} / \mathrm{C}\right)^{-1}$ in the first cycle is obviously the biggest challenge for the practical application of the $\mathrm{FeTiO}_{3} / \mathrm{C}$ electrodes. Nevertheless, this problem can probably be resolved by using appropriate conducting agents other than acetylene black (AB), because the high irreversible capacity likely originates from the side reactions between the electrolyte and $\mathrm{AB}$ (Fig. S1, Supporting Information). In the second cycle, the electrode exhibits a high reversible capacity of $403 \mathrm{mAh}\left(\mathrm{g}-\mathrm{FeTiO}_{3} / \mathrm{C}\right)^{-1}$, which corresponds to approximately $76 \%$ of the theoretical capacity based on a three-electron reaction $\left(530 \mathrm{mAh} \mathrm{g}^{-1}\right)$. In the subsequent cycles, 
a remarkably stable charge-discharge behavior is observed. The reversible capacity of the $\mathrm{FeTiO}_{3} / \mathrm{C}$ electrode is similar to that (about $410 \mathrm{mAh} \mathrm{g}{ }^{-1}$ ) reported for the $\mathrm{FeTiO}_{3}$-based negative electrode with tiny ilmenite $\mathrm{FeTiO}_{3}$ nanoparticle embedded carbon nanotubes in an organic electrolyte at $25^{\circ} \mathrm{C}$ [24]. For comparison, charge-discharge measurements were also conducted for the $\mathrm{FeTiO}_{3} / \mathrm{C}$ electrode at $25{ }^{\circ} \mathrm{C}$ in the ionic liquid electrolyte and an organic electrolyte ( $1 \mathrm{M} \mathrm{NaPF}_{6}$ in ethylene carbonate/dimethyl carbonate (EC-DMC, 1:1 in volume)). As shown in Fig. S2 (Supporting Information), the $\mathrm{FeTiO}_{3} / \mathrm{C}$ electrode exhibits a reversible capacity of about $120 \mathrm{mAh} \mathrm{g}^{-1}$ in the ionic liquid at $25^{\circ} \mathrm{C}$. The capacity is lower than that at 90 ${ }^{\circ} \mathrm{C}$ because of the high viscosity and low conductivity of the ionic liquid at $25{ }^{\circ} \mathrm{C}$ [26]. Thus, the $\mathrm{FeTiO}_{3} / \mathrm{C}$ electrode in the ionic liquid electrolyte is suitable to be operated at high temperature. In the $\mathrm{NaPF}_{6} / \mathrm{EC}$-DMC electrolyte at $25{ }^{\circ} \mathrm{C}$, the reversible capacity is about 150 $\mathrm{mAh} \mathrm{g}^{-1}$, which is lower than that measured in the ionic liquid at $90{ }^{\circ} \mathrm{C}$. The value is also lower than that reported for the $\mathrm{FeTiO}_{3}$-based electrode in an organic electrolyte at $25^{\circ} \mathrm{C}$ [24]. The low discharge capacity in the $\mathrm{NaPF}_{6} / \mathrm{EC}-\mathrm{DMC}$ at $25{ }^{\circ} \mathrm{C}$ may be attributed to the poor compatibility with PAI binder. The combination of $\mathrm{FeTiO}_{3} / \mathrm{C}, \mathrm{PAI}$ binder and $\mathrm{NaPF}_{6} / \mathrm{EC}-\mathrm{DMC}$ does not seem to be suitable for high performance because some change has occurred on the electrode after measurement. Further optimization of electrode is needed to improve the chargedischarge performance of the $\mathrm{FeTiO}_{3} / \mathrm{C}$ electrode in the organic electrolyte at $25^{\circ} \mathrm{C}$.

Rate capability is also an important parameter to characterize the electrochemical performance. Figure $2 \mathrm{~b}$ shows the charge-discharge curves of the $\mathrm{FeTiO}_{3} / \mathrm{C}$ electrode at current rates of 10-2000 $\mathrm{mA} \mathrm{g}^{-1}$. Although the polarization between the charge and discharge processes increases with the increasing current rate, the shape of the charge-discharge curves remains almost unchanged. Figure $2 \mathrm{c}$ shows the discharge capacities of the $\mathrm{FeTiO}_{3} / \mathrm{C}$ electrode at different current rates. At a current rate of $200 \mathrm{~mA} \mathrm{~g}^{-1}$, the discharge capacity is $326 \mathrm{mAh} \mathrm{g}^{-1}$, which corresponds to $81 \%$ of the discharge capacity at $10 \mathrm{~mA} \mathrm{~g}^{-1}$. When the current rate 
increases to $2000 \mathrm{~mA} \mathrm{~g}^{-1}$, the discharge capacity is $256 \mathrm{mAh} \mathrm{g}^{-1}$, which corresponds to $64 \%$ of the discharge capacity at $10 \mathrm{~mA} \mathrm{~g}^{-1}$. Thus, the $\mathrm{FeTiO}_{3} / \mathrm{C}$ electrode is confirmed to have a good rate capability.

Cycle performance is another important parameter, especially for practical application of the $\mathrm{FeTiO}_{3} / \mathrm{C}$ electrodes. Figure $2 \mathrm{~d}$ shows the cycle performance of the $\mathrm{FeTiO}_{3} / \mathrm{C}$ electrode at a current rate of $500 \mathrm{~mA} \mathrm{~g}^{-1}$ for 2000 cycles. In the first cycle, the discharge capacity is 241 $\mathrm{mAh} \mathrm{g}^{-1}$ with a coulombic efficiency of $55.8 \%$. The discharge capacity increases gradually with the cycle number, and reaches $275 \mathrm{mAh} \mathrm{g}^{-1}$ at the 200th cycle with a coulombic efficiency of $99.9 \%$. After 500, 1000, 1600, and 2000 cycles, the discharge capacities are 280, 282, 280, and $274 \mathrm{mAh} \mathrm{g}^{-1}$, respectively, with coulombic efficiencies higher than $99.9 \%$. As far as we know, such excellent cycle performance has never been reported for transition metal oxide materials.

Table 1 compares the reversible capacities, cycle performance and high rate capacities of the negative electrode materials reported so far as well as the $\mathrm{FeTiO}_{3} / \mathrm{C}$. Alloying materials, such as $\mathrm{Sn} \mathrm{[29]} \mathrm{and} \mathrm{SnSb} / \mathrm{C}$ [30], show high reversible capacities of larger than $500 \mathrm{mAh} \mathrm{g}^{-1}$, which is higher than that of the $\mathrm{FeTiO}_{3} / \mathrm{C}\left(403 \mathrm{mAh} \mathrm{g}^{-1}\right)$. However, due to the volume expansion correlated with the structure destruction of the electrodes during cycling, the alloying materials generally exhibit poor cycle performance and low rate capability. Compared with the alloy electrodes, the $\mathrm{FeTiO}_{3} / \mathrm{C}$ negative electrode shows excellent cycle performance and higher rate capability. Carbon materials, such as hard-carbon [31], carbon black [32] and hollow carbon [33], deliver reversible capacities of 200-300 $\mathrm{mAh} \mathrm{g}^{-1}$ with relatively good cycle performance and rate capability. Compared with the carbon materials, the $\mathrm{FeTiO}_{3} / \mathrm{C}$ negative electrode shows higher reversible capacity, better cycle performance and higher rate capability. Among oxide electrode materials, $\mathrm{Fe}_{2} \mathrm{O}_{3} / \mathrm{C}$ [19], $\mathrm{Co}_{3} \mathrm{O}_{4} / \mathrm{C}$ [21], $\mathrm{MoO}_{3}$ [22], $\mathrm{SnO}_{2}$ [34], and $\mathrm{NiCo}_{2} \mathrm{O}_{4} / \mathrm{C}$ [35] exhibit reversible capacities of higher than $400 \mathrm{mAh} \mathrm{g}^{-1}$, exceeding the capacity of the $\mathrm{FeTiO}_{3} / \mathrm{C}$. Concerning the titanium-based oxides, $\mathrm{TiO}_{2} / \mathrm{C}$ [23], $\mathrm{NaFeTiO}_{4}$ [36], $\mathrm{Na}_{2} \mathrm{Ti}_{3} \mathrm{O}_{7}$ [37] and 
$\mathrm{Na}_{2} \mathrm{Ti}_{6} \mathrm{O}_{13}$ [38] show reversible capacities of less than $300 \mathrm{mAh} \mathrm{g}^{-1}$, which is lower than that of the $\mathrm{FeTiO}_{3} / \mathrm{C}$. Compared with the reported oxide materials, the $\mathrm{FeTiO}_{3} / \mathrm{C}$ negative electrode shows better cycle performance and higher rate capability. In comparison with the $\mathrm{FeTiO}_{3}-$ based negative electrode with tiny ilmenite $\mathrm{FeTiO}_{3}$ nanoparticle embedded carbon nanotubes (carbon content: $28.69 \mathrm{wt} \%$ ) [24], the $\mathrm{FeTiO}_{3} / \mathrm{C}$ (carbon content: $4.8 \mathrm{wt} \%$ ) negative electrode exhibits almost the same reversible capacity and the high rate capability. Concerning the cycle retention, however, the $\mathrm{FeTiO}_{3} / \mathrm{C}$ negative electrode (97\% after 2000 cycles) shows higher performance than the tiny ilmenite $\mathrm{FeTiO}_{3}$ nanoparticle embedded carbon nanotubes $(90 \%$ after 2000 cycles [24]). Thus, the $\mathrm{FeTiO}_{3} / \mathrm{C}$ is concluded to be a promising negative material for sodium-ion batteries because of its high reversible capacity, excellent cycle performance and high rate capability.

The electrochemical sodiation-desodiation mechanism for the $\mathrm{FeTiO}_{3} / \mathrm{C}$ electrode was analyzed by ex situ XRD, as shown in Fig. 3. During the charge process (sodiation), the pristine $\mathrm{FeTiO}_{3}$ crystal phase gradually disappears. There is no significant change in the XRD pattern for the pristine electrode (electrode-1) and 0.8 V-charged electrode (electrode-2), except for the peak intensity. While charging to $0.5 \mathrm{~V}$ (electrode-3), a second phase grows at the expense of the pristine one. Here, the pristine $\mathrm{FeTiO}_{3}$ crystal phase is still detectable with a weak peak intensity. When the electrode is charged to $0.01 \mathrm{~V}$ (electrode-5), the pristine $\mathrm{FeTiO}_{3}$ crystal phase completely disappears and only the new crystal phase is detected. Since the new crystal phase is very similar to $\mathrm{Na}_{0.54} \mathrm{TiO}_{2}$ (JCPDS file No. 01-080-1053) (Fig. S3a, Supporting Information), the $\mathrm{Na}_{\mathrm{x}} \mathrm{TiO}_{2}(0.5<\mathrm{x}<1)$ crystal phase is likely formed in the charged electrode. If $\mathrm{Na}_{\mathrm{x}} \mathrm{TiO}_{2}$ is formed, the metallic Fe phase should be generated. However, no Fe crystal phase is detected in the XRD pattern, indicating that the formed Fe phase is amorphous. To investigate the oxidation state of Fe atoms, X-ray photoelectron spectroscopy (XPS) was carried out for the electrode charged to $0.01 \mathrm{~V}$. As shown in Fig. S4 (Supporting Information), $\mathrm{Fe}^{2+}$ and $\mathrm{Fe}^{0}$ 
are present in the charged electrode, indicating the formation of amorphous Fe formed in the electrode. In addition, according to the sodiation mechanism of $\mathrm{Fe}_{2} \mathrm{O}_{3}$, where $\mathrm{Fe}_{2} \mathrm{O}_{3}$ is converted into $\mathrm{Fe}$ and $\mathrm{Na}_{2} \mathrm{O}[14,16], \mathrm{Na}_{2} \mathrm{O}$ should be formed in the charged electrode.

During the discharge process (desodiation), from electrode-5 to electrode-10, the formed $\mathrm{Na}_{\mathrm{x}} \mathrm{TiO}_{2}$ crystal phase gradually disappears, and other crystal phase is formed. The formed crystal phase in electrode-10 is well consistent with the $\mathrm{FeTiO}_{3}$ crystal phase (Fig. S3b, Supporting Information), indicating the recovery of the pristine $\mathrm{FeTiO}_{3}$ crystal phase during the desodiation process. XPS analysis of electrode-10 also shows that the main oxidation state of $\mathrm{Fe}$ is $\mathrm{Fe}^{2+}$ (Fig. S4, Supporting Information). Thus, the reversible sodiation-desodiation reaction is summarized as follows: in the charging process, $\mathrm{Na}$ ions are electrochemically reduced and react with $\mathrm{FeTiO}_{3}$ to form $\mathrm{Na}_{x} \mathrm{TiO}_{2}, \mathrm{Fe}$, and $\mathrm{Na}_{2} \mathrm{O}$; in the discharging process, the products are converted back to $\mathrm{FeTiO}_{3}$ and $\mathrm{Na}$ ions. The highly reversible sodiation/desodiation processes, in addition to the carbon coating, contribute to the excellent cycle performance of the $\mathrm{FeTiO}_{3} / \mathrm{C}$ electrode.

To investigate the microscopic morphological changes of the $\mathrm{FeTiO}_{3} / \mathrm{C}$ electrodes during the sodiation-desodiation processes, ex situ SEM analysis was carried out and the results are shown in Fig. 4. For reference, the SEM image of a pristine electrode is shown in Fig. 4a. When the electrode is charged to $0.5 \mathrm{~V}$, some round particles form on the surface (Fig. 4b). These round particles grow in size when being charged to $0.01 \mathrm{~V}$ (Fig. 4c), and are still present when the electrode is discharged to $2.5 \mathrm{~V}$ (Fig. 4d). Since the formation of round particles is irreversible, the formation is likely due to the electrolyte reduction in the first charge process, as shown in Figure 2a. The formation of round particles has been also observed for the $\mathrm{TiO}_{2} / \mathrm{C}$ electrode in the same electrolyte, where the energy dispersive X-ray analysis of the round particles reveals that it resulted from electrolyte reduction [28]. In addition, the electrode charged to $0.01 \mathrm{~V}$ has some needle-like particles (Fig. 4c). When the electrode is discharged to $2.5 \mathrm{~V}$, the needle-like 
particles disappear (Fig. 4d), indicating that the formation of these particles is reversible.

\section{Conclusions}

In summary, we have reported $\mathrm{FeTiO}_{3} / \mathrm{C}$ as a negative electrode material for sodiumion batteries. The $\mathrm{FeTiO}_{3} / \mathrm{C}$ electrode exhibits a high reversible capacity of $403 \mathrm{mAh} \mathrm{g}^{-}$ ${ }^{1}$ with outstanding cycling stability for up to 2000 cycles. We have also elucidated the sodiation-desodiation mechanism of the $\mathrm{FeTiO}_{3} / \mathrm{C}$ electrode. These results have the potential to greatly contribute toward the development of sodium-ion batteries. We also believe that our results can provide a guidepost for exploring new negative electrode materials for sodium-ion batteries with high energy density and long cycle lives.

\section{Acknowledgements}

This study was partly supported by the Advanced Low Carbon Technology Research and Development Program (ALCA, No. 3428) of the Japan Science and Technology Agency (JST), and the "Elements Strategy Initiative to Form Core Research Center" program of the Japanese Ministry of Education, Culture, Sports, Science and Technology (MEXT).

\section{References}

[1] N. Yabuuchi, M. Kajiyama, J. Iwatate, H. Nishikawa, S. Hitomi, R. Okuyama, R. Usui, Y. Yamada, S. Komaba, Nat. Mater. 11 (2012) 512-517. 
[2] S. W. Kim, D. H. Seo, X. H. Ma, G. Ceder, K. Kang, Adv. Energy Mater. 2 (2012) 710721.

[3] V. Palomares, P. Serras, I. Villaluenga, K. B. Hueso, J. Carretero-Gonzalez, T. Rojo, Energy Environ. Sci. 5 (2012) 5884-5901.

[4] K. M. Abraham, Solid State Ionics 7 (1982) 199-212.

[5] L. Wu, X. H. Hu, J. F. Qian, F. Pei, F. Y. Wu, R. J. Mao, X. P. Ai, H. X. Yang, Y. L. Cao, Energy Environ. Sci. 7 (2014) 323-328.

[6] Y. H. Liu, Y. H. Xu, Y. J. Zhu, J. N. Culver, C. A. Lundgren, K. Xu, C. S. Wang, ACS Nano 7 (2013) 3627-3634.

[7] X. Q. Xie, K. Kretschmer, J. Q. Zhang, B. Sun, D. W. Su, G. X. Wang, Nano Energy $13(2015)$ 208-217.

[8] Y. H. Xu, Y. J. Zhu, Y. H. Liu, C. S. Wang, Adv. Energy Mater. 3 (2013) 128-133.

[9] S. Komaba, W. Murata, T. Ishikawa, N. Yabuuchi, T. Ozeki, T. Nakayama, A. Ogata, K. Gotoh, K. Fujiwara, Adv. Funct. Mater. 21 (2011) 3859-3867.

[10] J. Zhao, L. W. Zhao, K. Chihara, S. Okada, J. Yamaki, S. Matsumoto, S. Kuze, K. Nakane, J. Power Sources 244 (2013) 752-757.

[11] J. Ding, H. L. Wang, Z. Li, A. Kohandehghan, K. Cui, Z. W. Xu, B. Zahiri, X. H. Tan, E. M. Lotfabad, B. C. Olsen, D. Mitlin, ACS Nano 7 (2013) 11004-11015.

[12] Y. L. Cao, L. F. Xiao, M. L. Sushko, W. Wang, B. Schwenzer, J. Xiao, Z. M. Nie, L. V. Saraf, Z. G. Yang, J. Liu, Nano Lett. 12 (2012) 3783-3787.

[13] R. Alcantara, M. Jaraba, P. Lavela, J. L. Tirado, Chem. Mater. 14 (2002) 2847-2848.

[14] Y. Z. Jiang, M. J. Hu, D. Zhang, T. Z. Yuan, W. P. Sun, B. Xu, M. Yan, Nano Energy 5 (2014) 60-66.

[15] I. Hasa, R. Verrelli, J. Hassoun, Electrochim. Acta 173 (2015) 613-618. 
[16] M. Valvo, F. Lindgren, U. Lafont, F. Bjorefors, K. Edstrom, J. Power Sources 245 (2014) 967-978.

[17] K. T. Kim, G. Ali, K. Y. Chung, C. S. Yoon, H. Yashiro, Y. K. Sun, J. Lu, K. Amine, S. T. Myung, Nano Lett. 14 (2014) 416-422.

[18] J. C. Perez-Flores, C. Baehtz, A. Kuhn, F. Garcia-Alvarado, J. Mater. Chem. A 2 (2014) 1825-1833.

[19] Z. L. Jian, B. Zhao, P. Liu, F. J. Li, M. B. Zheng, M. W. Chen, Y. Shi, H. S. Zhou, Chem. Commun. 50 (2014) 1215-1217.

[20] M. M. Rahman, A. M. Glushenkov, T. Ramireddy, Y. Chen, Chem. Commun. 50 (2014) 5057-5060.

[21] Y. Wang, C. Y. Wang, Y. J. Wang, H. K. Liu, Z. G. Huang, J. Mater. Chem. A 4 (2016) 5428-5435.

[22] S. Hariharan, K. Saravanan, P. Balaya, Electrochem. Commun. 31 (2013) 5-9.

[23] C. S. Ding, T. Nohira, R. Hagiwara, J. Mater. Chem. A 3 (2015) 20767-20771.

[24] L. Yu, J. Liu, X. Xu, L. Zhang, R. Hu, J. Liu, L. Ouyang, L. Yang, M. Zhu, ACS Nano 11 (2017) 5120-5129.

[25] C. S. Ding, T. Nohira, K. Kuroda, R. Hagiwara, A. Fukunaga, S. Sakai, K. Nitta, S. Inazawa, J. Power Sources 238 (2013) 296-300.

[26] C. S. Ding, T. Nohira, R. Hagiwara, K. Matsumoto, Y. Okamoto, A. Fukunaga, S. Sakai, K. Nitta, S. Inazawa, J. Power Sources 269 (2014) 124-128.

[27] G. A. Giffin, J. Mater. Chem. A 4 (2016) 13378-13389.

[28] C. S. Ding, T. Nohira, R. Hagiwara, Phys. Chem. Chem. Phys. 18 (2016) 30770-30776.

[29] Y. M. Lin, P. R. Abel, A. Gupta, J. B. Goodenough, A. Heller, C. B. Mullins, ACS Appl. Mater. Interfaces 5 (2013) 8273-8277. 
[30] L. Xiao, Y. Cao, J. Xiao, W. Wang, L. Kovarik, Z. Nie, J. Liu, Chem. Commun. 48 (2012) 3321-3323.

[31] C. S. Ding, T. Nohira, R. Hagiwara, A. Fukunaga, S. Sakai, K. Nitta, Electrochim. Acta 176 (2015) 344-349.

[32] W. Xiao, Q. Sun, J. Liu, B. Xiao, P. Glans, J. Li, R. Li, J. Guo, W. Yang, T. Sham, X. Sun, Nano Res., 2017, https://doi.org/10.1007/s12274-017-1852-4.

[33] Y. L. Cao, L. F. Xiao, M. L. Sushko, W. Wang, B. Schwenzer, J. Xiao, Z. M. Nie, L.V. Saraf, Z. G. Yang, J. Liu, Nano Lett. 12 (2012) 3783-3787.

[34] D. Su, C. Wang, H. Ahn, G. Wang, Phys. Chem. Chem. Phys. 15 (2013) 12543-12550.

[35] Y. Wang, H. Huang, Q. Xie, Y. Wang, B. Qu, J. Alloys Compounds 705 (2017) 314319.

[36] J. Wang, B. Qiu, X. He, T. Risthaus, H. D. Liu, M. C. Stan, S. Schulze, Y. G Xia, Z. P. Liu, M. Winter, J. Li, Chem. Mater. 27 (2015) 4374-4379.

[37] A. Rudola, K. Saravanan, C.W. Mason, P. Balaya, J. Mater. Chem. A 1 (2013) 26532662.

[38] A. Rudola, K. Saravanan, S. Devaraj, H. Gong, P. Balaya, Chem. Commun. 49 (2013) $7451-7453$. 

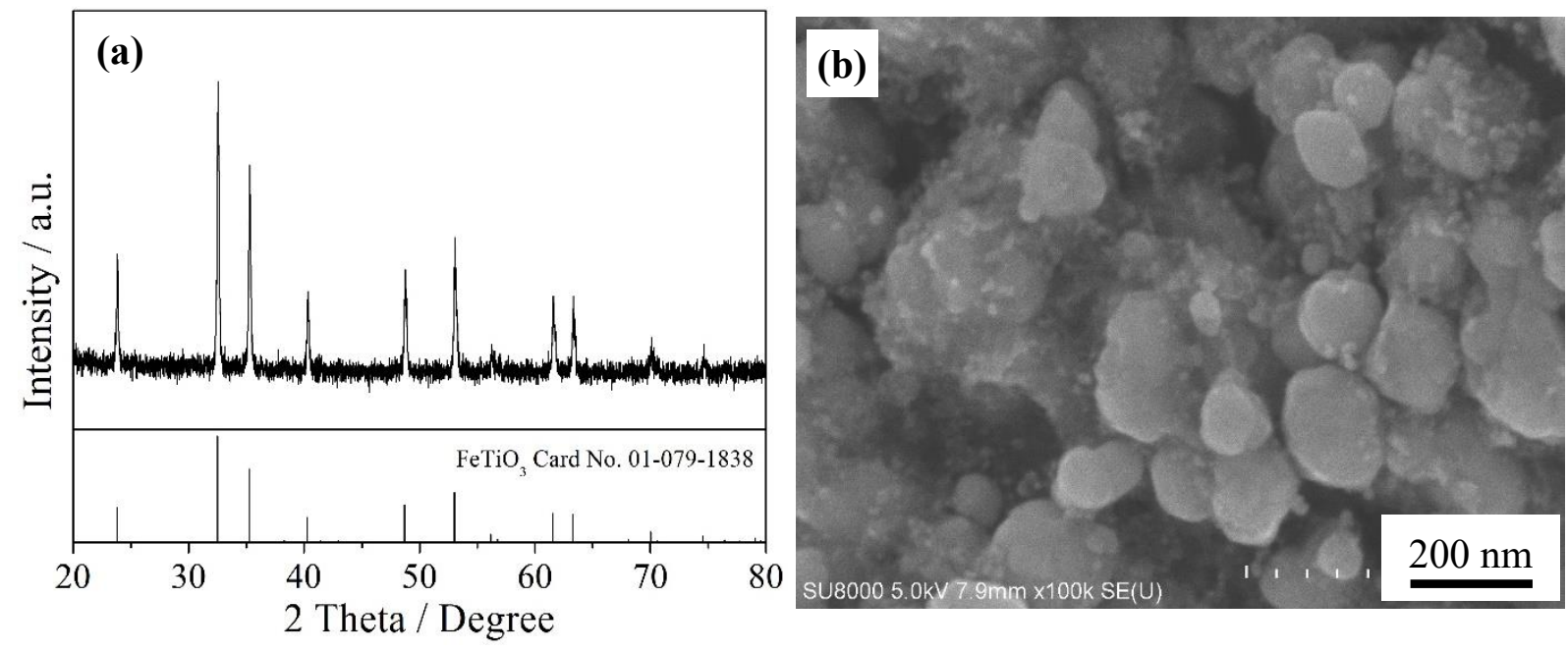

Fig. 1 (a) XRD pattern and (b) SEM image of $\mathrm{FeTiO}_{3} / \mathrm{C}$ nanoparticles. 
(a)
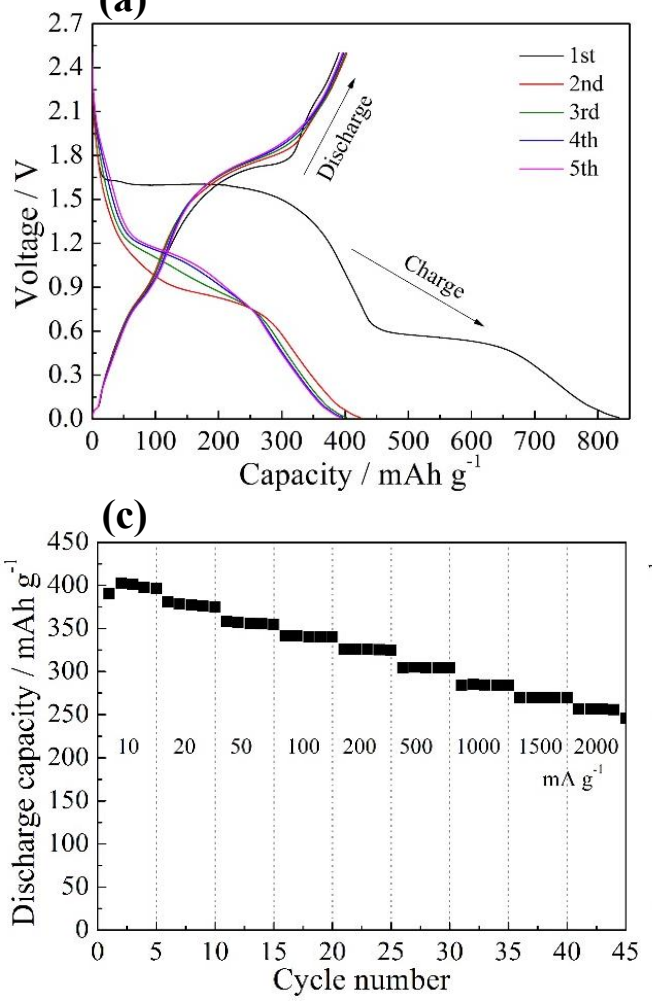

(b)

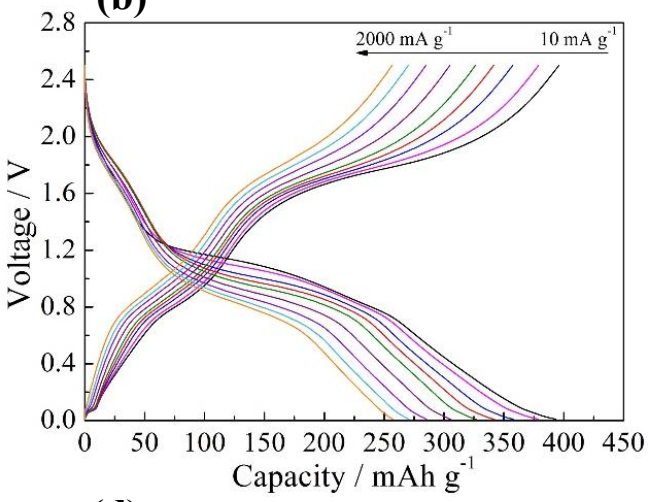

(d)

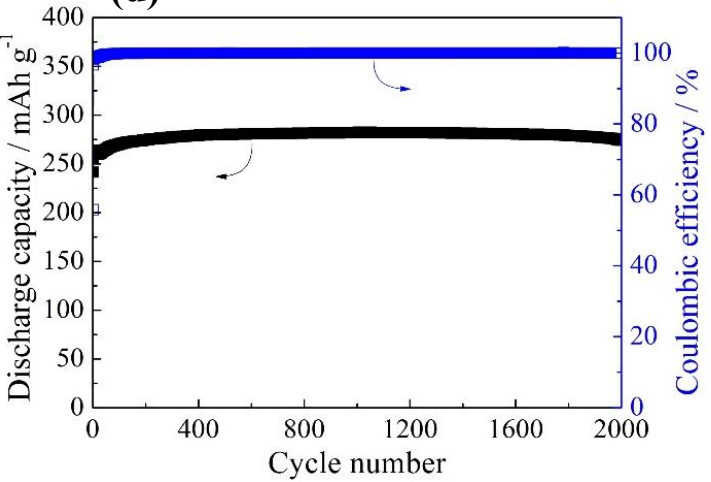

Fig. 2 Electrochemical performance of $\mathrm{FeTiO}_{3} / \mathrm{C}$ electrode. (a) Charge-discharge curves at a current rate of $10 \mathrm{~mA} \mathrm{~g}^{-1}$ in the voltage range of $0.01-2.5 \mathrm{~V}$. (b) Charge-discharge curves at current rates of 10, 20, 50, 100, 200, 500, 1000, 1500, and $2000 \mathrm{~mA} \mathrm{~g}^{-1}$. (c) Rate capability. d) Cycle performance at a current rate of $500 \mathrm{~mA} \mathrm{~g}^{-1}$. 
(a)

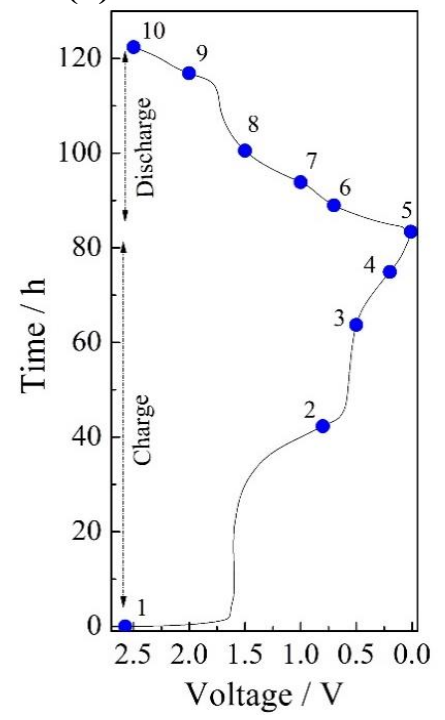

(b)

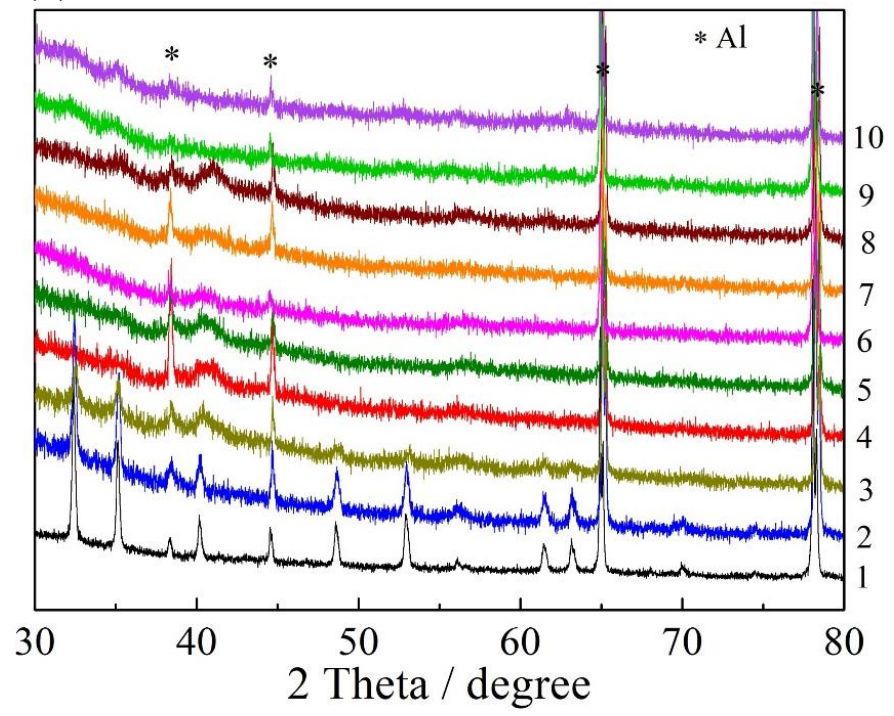

Fig. 3 Electrochemical and structural characterization of the $\mathrm{FeTiO}_{3} / \mathrm{C}$ electrode. a) Chargedischarge curves at $10 \mathrm{~mA} \mathrm{~g}^{-1}$ in the first cycle. The numbers indicate the charged and discharged states of the $\mathrm{FeTiO}_{3} / \mathrm{C}$ electrode. b) Ex situ XRD patterns of the $\mathrm{FeTiO}_{3} / \mathrm{C}$ electrode at various charge/discharge stages: (1) pristine electrode, (2) electrode charged to $0.8 \mathrm{~V}$, (3) electrode charged to $0.5 \mathrm{~V}$, (4) electrode charged to $0.2 \mathrm{~V}$, (5) electrode charged to $0.01 \mathrm{~V}$, (6) electrode discharged to $0.7 \mathrm{~V}$, (7) electrode discharged to $1.0 \mathrm{~V}$, (8) electrode discharged to 1.5 $\mathrm{V}$, (9) electrode discharged to $2.0 \mathrm{~V}$, and (10) electrode discharged to $2.5 \mathrm{~V}$, as indicated in (a). 

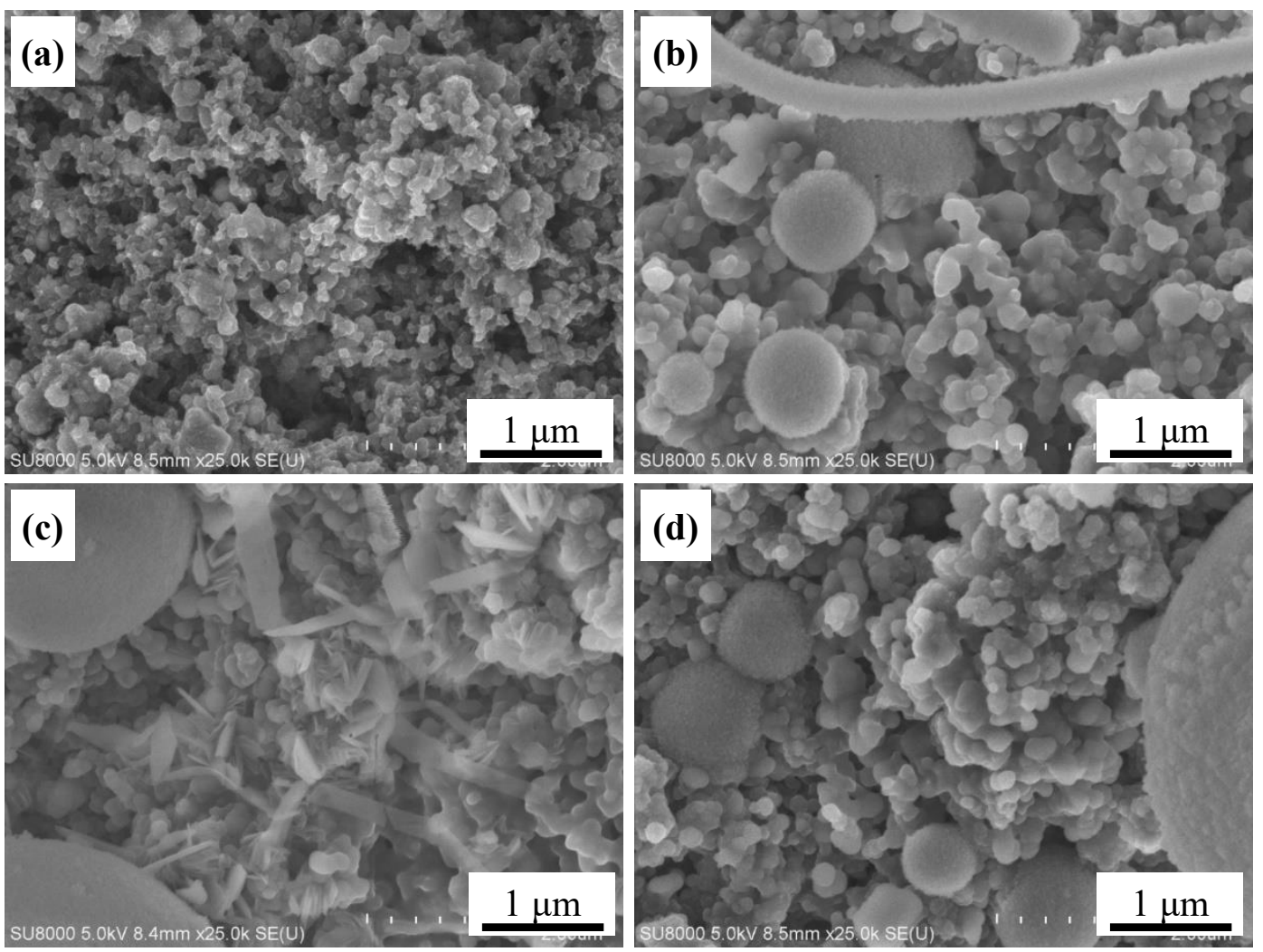

Fig.4 SEM observation of $\mathrm{FeTiO}_{3} / \mathrm{C}$ electrodes with different charge-discharge states. a) Pristine electrode. b) Electrode charged to 0.5 V. c) Electrode charged to 0.01 V. d) Electrode discharged to $2.5 \mathrm{~V}$. 
Table 1 Electrochemical performance of negative electrode materials reported so far for sodium-ion batteries.

\begin{tabular}{|c|c|c|c|c|c|c|c|}
\hline \multirow{2}{*}{$\begin{array}{l}\text { Electrode } \\
\text { materials }\end{array}$} & \multirow{2}{*}{$\begin{array}{c}\text { Reversible } \\
\text { capacity }\left(\mathrm{mAh} \mathrm{g}^{-1}\right)\end{array}$} & \multicolumn{4}{|c|}{ Cycle retention (\%) after $\mathrm{N}$ cycles } & \multirow{2}{*}{$\begin{array}{c}\text { High rate } \\
\text { capacity } \\
\left(\mathrm{mAh} \mathrm{g}^{-1}\right) \\
\left(\text { rate }\left(\mathrm{mA} \mathrm{g}^{-1}\right)\right)\end{array}$} & \multirow{2}{*}{ Reference } \\
\hline & & 100 & 500 & 1000 & 2000 & & \\
\hline $\mathrm{Sn}$ & 510 & 49 & - & - & - & $222(422)$ & 29 \\
\hline $\mathrm{SnSb} / \mathrm{C}$ & 544 & $80 *$ & - & - & - & $274(1000)$ & 30 \\
\hline Hard carbon & 277 & 94 & 84 & - & - & $230(1000)$ & 31 \\
\hline Carbon black & 234 & 79 & 57 & 56 & 57 & $159(400)$ & 32 \\
\hline $\begin{array}{l}\text { Hollow } \\
\text { carbon }\end{array}$ & 251 & 90 & $82 * *$ & - & - & $149(500)$ & 33 \\
\hline $\mathrm{TiO}_{2} / \mathrm{C}$ & 275 & 91 & 89 & 79 & - & $174(500)$ & 23 \\
\hline $\mathrm{SnO}_{2}$ & 510 & 85 & - & - & - & $250(160)$ & 34 \\
\hline $\mathrm{Co}_{3} \mathrm{O}_{4} / \mathrm{C}$ & 516 & 94 & 80 & 67 & - & $263(1000)$ & 21 \\
\hline $\mathrm{MoO}_{3}$ & 410 & 88 & 55 & - & - & $158(559)$ & 22 \\
\hline $\mathrm{Fe}_{2} \mathrm{O}_{3} / \mathrm{C}$ & 535 & 77 & - & - & - & $260(500)$ & 19 \\
\hline $\mathrm{NiCO}_{2} \mathrm{O}_{4} / \mathrm{C}$ & 440 & 90 & - & - & - & $180(800)$ & 35 \\
\hline $\mathrm{NaFeTiO}_{4}$ & 181 & 99 & 98 & - & - & 68 (354) & 36 \\
\hline $\mathrm{Na}_{2} \mathrm{Ti}_{3} \mathrm{O}_{7}$ & 177 & $65^{*}$ & - & - & - & $100(356)$ & 37 \\
\hline $\mathrm{Na}_{2} \mathrm{Ti}_{6} \mathrm{O}_{13}$ & 42 & 89 & 87 & - & - & 15 (495) & 38 \\
\hline $\begin{array}{l}\mathrm{FeTiO}_{3} \text {-carbon } \\
\text { nanotubes }\end{array}$ & 410 & 99 & 96 & 96 & 90 & 273 (1000) & 24 \\
\hline $\mathrm{FeTiO}_{3} / \mathrm{C}$ & 403 & 99 & 99 & 99 & 97 & 285 (1000) & This study \\
\hline
\end{tabular}

